\title{
An integrated airborne laser scanning approach to forest management and cultural heritage issues: a case study at Porolissum, Romania
}

\author{
A. Roman, T.-M. Ursu, S. Fărcaș, V.-A. Lăzărescu, C.H. Opreanu
}

Roman A., Ursu T.-M., Fărcaș S., Lăzărescu V.-A., Opreanu C.H., 2017. An integrated airborne laser scanning approach to forest management and cultural heritage issues: a case study at Porolissum, Romania. Ann. For. Res. 60(1): 127-143.

Abstract. This paper explores the opportunities that arise where forest ecosystem management and cultural heritage monuments protection converge. The case study area for our analysis was the landscape surrounding the Moigrad-Porolissum Archaeological site. We emphasize that an Airborne Laser Scanning (ALS or LiDAR-Light Detection and Ranging) approach to both forest management and cultural heritage conservation is an outstanding tool, assisting policy-makers and conservationists in decision making for integrated planning and management of the environment. LiDAR-derived surface models enabled a synoptic, never-seen-before view of the ancient Roman frontiers defensive systems while also revealing the present forest road network. The thorough and accurate road inventory data are very useful for updating and modifying forest base maps and registries and also for identifying the priority sectors for archaeological discharge. The ability to identify and determine optimal routes for forest management and to locate previously unmapped ancient archaeological remains aids in reducing costs and creating operational efficiencies as well as in complying with the legislation and avoiding infringements. The potential of LiDAR to demonstrate the long-term and comprehensive human impact on wooded areas is discussed. We identified a significant historical landscape change, consisting of a deforestation period, spanning over more than 160 years, during the Roman Period in Dacia (106-271 AD). The transdisciplinary analysis of the LiDAR data provides the base for combining knowledge from archaeology, forestry and environmental history in order to achieve a thorough analysis of the landscape changes and history. In the "nature versus culture" dichotomy, the landscape, outfield areas and forests are primarily perceived as nature, while in reality they are often heavily marked by human impact. LiDAR offers an efficient method for broadening our knowledge regarding the character and extent of human interaction with landscapes - forested or otherwise. Keywords forest ecosystem management, cultural heritage management, landscape history, land use legacy, LiDAR, ancient Roman Period.

Authors. Anamaria Roman, Tudor-Mihai Ursu (tudor.ursu@icbcluj.ro), Sorina Fărcaş - Institute of Biological Research Cluj-Napoca, National Institute of Research and Development for Biological Sciences, 48 Republicii Street, 400015 Cluj-Napoca, Romania; Vlad-Andrei Lăzărescu, Coriolan Horaţiu Opreanu - 
Institute of Archaeology and History of Art Cluj-Napoca, Romanian Academy, 12-14 Kogălniceanu Street, 400084 Cluj-Napoca, Romania.

Manuscript received May 5th, 2016; revised December 29, 2016; accepted March 03, 2017; online first March 10, 2017.

\section{Introduction}

Knowledge of the environmental history can guide policy-makers and conservationists in their decision making for the integrated planning and management of the landscape, comprising both forest and cultural heritage resources (Foster et al. 2003, Chew 2008, Chauchard et al. 2013). The World Cultural and Natural Heritage (WCNH) convention established an international instrument protecting both the cultural and natural heritage of exceptional global value. The convention stated that "natural heritage encompasses outstanding physical, biological and geological formations, habitats of threatened species, areas with scientific conservation or aesthetic value", whereas "the cultural heritage comprises monuments, groups of buildings, or sites with historical, aesthetic, archaeological, scientific, ethnological or anthropological value" (UNESCO 1972, Articles 1 and 2 of the WCNH). Also, at national level, landscape protection aims to preserve the representative features of a landscape whose patrimony value may be justified by its natural configuration and/or human activity (Anonymous 2000, Anonymous 2001a, b, Anonymous 2002).

Anthropogenic and natural factors act together and continuously alter the landscape, involving not only the present forest resources but also the cultural heritage resources (Risbøl et al. 2015). In order to disentangle past human activities and their enduring effects from present impacts, it is important to map the cultural heritage and historical land uses and aquire a comprehensive perspective (Foster et al., 2003). This is a difficult task especially when the archaeological remains are buried beneath the thick forest soil layer. Moreover, data on woodland development during different historical periods are essential for future monitoring programs that would prevent undesirable developments in areas of high cultural heritage and/or environmental importance (Birks 2005, Fraterrigo 2013).

The uncertain geographical positioning of the ancient archaeological vestiges in forested areas hinders the authorities from elaborating management and preservation plans for their protection. All ancient cultural heritage remains from Romania are legally protected by default (Anonymous 2001a, b), and complying with the law is a great challenge for both land owners and forest enterprises due to the lack of proper inventories. The main threats for the unknown archaeological remains are the mechanized operations like forest thinning, timber harvest and road building (Risbøl et al. 2006).

A detailed cultural remains map is a great tool for property owners and forest managers, helping them comply with the law, while it also serves historical ecology by revealing previous land use and its corresponding present legacies. Identifying the long-term effects of historic land use on forests helps broaden our understanding of anthropogenic disturbances and also pinpoints the factors which impact forest restoration (Foster et al. 2003). Mapping historical land-use for large forested areas has mainly been conducted using aerial photography, historical maps, old written documents and occasionally ground truthing carried out by archaeologists. Unfortunately, historical maps are only available for the Modern time (e.g. after 1700-1800 AD) and it was most often assumed that, prior to this period, the so-called ancient forest patches had never been extensively used for human settlements 
(e.g. ancient cities), agriculture, forestry or intensive military purposes (Foster et al. 2003, Dambrine et al. 2007, Ritter 2011).

Since for large South-Eastern European regions, including Romania, the historical landuse and abandonment processes are most often not documented, it is not possible to directly explore how the legacies of past land uses are reflected within the existing patterns of the modern forested landscape. LiDAR technology (Light Detection and Ranging or ALS-Airborne Laser Scanning) can help break this time barrier. This active remote sensing method allows visualizing the ground topography over large areas even under the forest canopy and reveals the legacies of historical land use. The use of LiDAR can also help researchers address several issues associated with these legacies and their reflection in present forest canopy patterns (Hightower et al. 2014). At the Moigrad-Porolissum Archaeological site (Sălaj County, Romania) the LiDAR-derived visualization models enabled the detection of 79 new, subsurface archaeological structures. The functional role of these structures, established according to the extant historical data, allowed the comprehensive interpretation of the ancient landscape. The synergy of these methods supported the hypothesis that the currently forested area was extensively deforested, for strategic purposes, during the Roman period (Roman et al. 2017).

LiDAR scanning employs pulses of light that are sent down in swaths. After hitting a reflective surface they are reflected back to the sensor, which records the time and intensity of return for the reflected pulses and, by employing a georeferencing system and GPS satellites, it represents the returns as points in three-dimensional space. They can be classified into first returns, reflected from the tree tops, intermediate returns, from the leaves or branches, and last returns, reflected from the ground. Aerial laser scanning has many uses: measuring agricultural productivity (Saeys et al. 2009), distinguishing faint archaeological evidences (Bennett 2012), forestry practices (Hyyppä et al. 2012), advancing the science of geomorphology (Sofia et al. 2014), measuring volcano uplift (Whelley et al. 2014), glacier decline and snowpack (Abermann et al. 2010), and providing data for topographic mapping, to name just a few. Using the LiDAR point cloud data, one can extract specific features, such as dimensions of underground ancient structures or aboveground parameters of individual trees (Popescu et al. 2003, Popescu 2007, Edson \& Wing 2011, Dalponte et al. 2014), and obtain ecosystem level information such as forests biomass or carbon sequestration capacity (Lefsky et al. 2005, Popescu 2007, García et al. 2010, Lee et al. 2013).

Since LiDAR is an interdisciplinary technology, it can be used to raise awareness regarding the social and cultural issues during forest harvest planning, especially in areas rich and famous for cultural heritage vestiges. Considering the high cost of data acquisition, the most effective approach is to employ the data in as many usage domains as possible. However, the transdisciplinary use of LiDAR data available from a particular area has rarely been accomplished (Harpold et al. 2015). In addition to ancient structures mapping, LiDAR provides accurate measurements of numerous forest inventory attributes at a level of detail that is unavailable to traditional forestry measurements (Popescu \& Wynne 2004, Wulder et al. 2008, Unger et al. 2014), facilitates forest road network mapping (White et al. 2010, Azizi et al. 2014), and the delineation of forest creeks and streams (Wulder et al. 2008, Roman et al. 2015). The detailed forest road network map provides essential information for forestry practices such as forest management, fire protection, transport of forest products and prevention of smuggling, but also for travel, recreation and education (White et al. 2010, Abdi et al. 2012).

The Moigrad-Porolissum Archaeological site, situated in a forested landscape, served as an example for the transdisciplinary analysis of LiDAR data for both cultural heritage protection and forest management operations. 
This approach also made possible to detect the traces of ancient human impact within the present vegetation structure and to assess habitat quality. The primary focus of this article is to explore how cultural heritage management and forestry practices may be best employed at the landscape level using the same LiDAR dataset. This case study illustrates the integration of forest heritage and forest ecosystem management, particularly regarding the spatial distribution and mapping of the present forest roads and of the ancient Roman military defensive system from Porolissum. The outcome of this article is a set of maps that would allow the Romanian National Forest Authorities to achieve efficient forest management while also complying with the existing European and national heritage legislation. Since many road segments, particularly the newly built ones, are not available in national maps, mapping the forest road network is a priority for forest managers. The main question raised was: in what way can LiDAR-derived data support both cultural and forest resources management and planning? Specifically, we explored how may the underground ancient archaeological remains be conserved and protected in the context of harvesting the forests growing above them by designing the present forest road network.

\section{Materials and methods}

\section{Study area}

The study area (Fig. 1) covers $10 \mathrm{~km}^{2}$ and includes the Archaeological Complex of Porolissum (Mirşid, Sălaj County, Romania) - 47 $11^{\prime} 49^{\prime \prime} \mathrm{N}, 23^{\circ} 08^{\prime} 37^{\prime \prime} \mathrm{E}, 504 \mathrm{~m}$ a.s.l. (Fig. 1b), as part of the Roman Empire Frontier fortification system in the Dacia Province, also called The Roman Empire Limes. The climate is warm and temperate, the annual averages being a temperature of $9.2^{\circ} \mathrm{C}$ and $647 \mathrm{~mm}$ of precipitation. The area surrounding Porolissum offered numerous strategic advantages for 130 the Romans due to its geographical position, being the only passing canyon connecting the north-western plains with the inner Transylvanian Plateau. As a consequence, huge military defensive works were laid out in the area (Gudea 1988).

Today, the remains of the Limes consist of vestiges of defense walls, ditches, forts, fortresses, watchtowers, civilian settlements and fortification structures, most of them being hidden underground and a few rebuilt (Gudea 1988, 1989, Opreanu et al. 2014). Within the study area, there are two archaeological sites that are already enlisted and protected as historical monuments (Anonymous 2000, 2001b), being representative for the Roman and respectively for the Dacian Period (Fig. 1c and $1 \mathrm{~d}$ ). The forested area (tree height $\geq 3 \mathrm{~m}$; forest cover $\geq 50 \%$ ), digitized from the aerial photography taken in 2009, covers 579.35 ha (Fig. 1c and 1d) and is managed by a private forest district, only a small part being under state ownership.

Many of the ancient archaeological structures were discovered in the grass-dominated landscape. They include some military structures: the big fort at Pomet Hill and its inner structure, the headquarters, and granaries; but also civilian habitation: several temples, the amphitheater, and a few private houses (Gudea 1989, Tamba 2008, Bajusz 2011). These early findings revealed most of the civilian settlement and part of the military defense system at Porolissum. However, the nearby Roman defensive system of the Dacian Province, located in an almost entirely forested area, mostly by oak, hornbeam, and beech trees (Roman et al. 2014), remained primarily unexplored by archaeologists until recently (Opreanu 1998, Opreanu \& Lăzărescu 2012).

Starting in 2011, within the research project PoroLIMES (Opreanu \& Lăzărescu 2012), the existing topographical information from the open grassland was centralized and all the previously known archaeological structures were mapped. The project also scheduled large scale geophysical surveys and archaeological exca- 


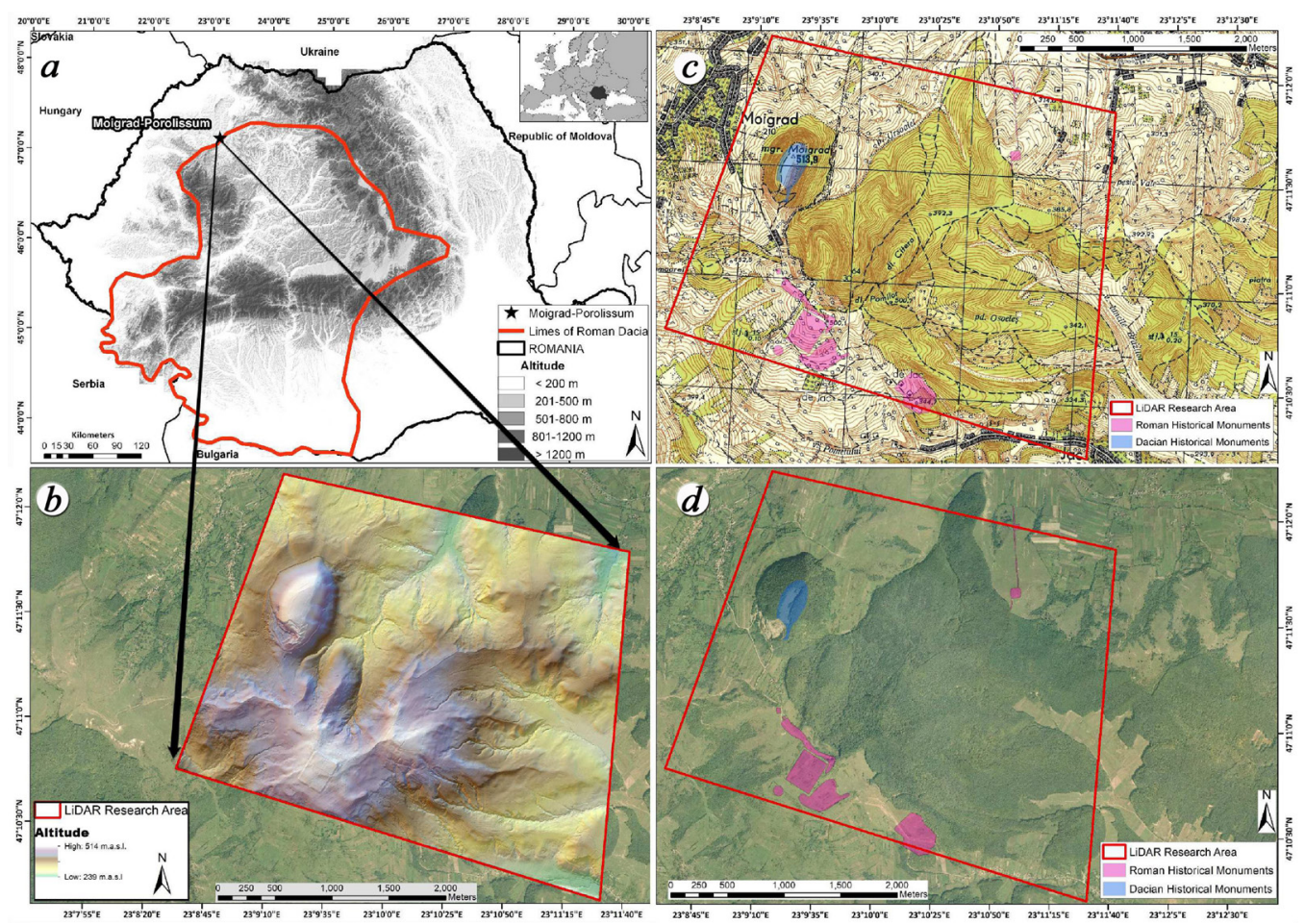

Figure 1 (a) The study site at Moigrad-Porolissum and the frontiers of the ancient Roman Dacia; (b) The LiDAR-research area and the derived digital terrain model; (c) The topographical map of the study area and the protected historical monuments; (d) The aerial photography of the study area and the protected historical monuments.

vations (Opreanu \& Lăzărescu 2012, Opreanu et al. 2013a, b) and paleoenvironmental studies (Grindean et al. 2014). It also included mapping of vegetation and topographical patterns in forested areas (Opreanu et al. 2014, Roman et al. 2014, Roman et al. 2016) and mapping small watersheds and wetland features from beneath the forest canopy.

\section{Data and analysis}

The integrated approach to forest management and cultural heritage matters was performed by employing the same LiDAR data for the mapping of archaeological remains and forest roads.

As part of the project PoroLIMES, LiDAR data were collected by ArcTron $\mathrm{GmbH}$, using a
D-EBMW/C207 helicopter, for a $10 \mathrm{~km}^{2}$ area, assumed to include significant ancient Roman Limes underground structures. LiDAR flight and sensor parameters are given in Table 1. The study area was covered with a total of 17 flight lines, overlapping 35-50\%, thus achieving over $150 \%$ coverage. The raw LiDAR points were first classified into ground points and vegetation points by the LiDAR data provider. The first filter was automatically applied using macros for ground point classification in the commercial software package TerraScan ${ }^{\mathrm{TM}}$ (Terrasolid, Ltd.). The classification routines and algorithms from this package employed the adaptive TIN filtering method described by Axelsson (2000). The absolute vertical accuracy, obtained by comparing LiDAR and ground DGPS elevation points, was evaluated 
to be less than $0.3 \mathrm{~m}$ in flat terrain, respectively less than $0.5 \mathrm{~m}$ in steep areas. The control procedures during the LiDAR data processing did not detect any position deviation outside of the targeted accuracy range $(+/-0.5 \mathrm{~m})$. The filtered point cloud tiles of the vegetation canopy (DSM - Digital Surface Model) and the filtered point cloud tiles of the ground topography (DTM) were delivered to us as separate ASCII xyz files, with X (longitude), Y (latitude) and $Z$ (elevation) coordinate values. The average point spacing density of ground returns was 0.40 points per square meter. A 0.5 $\mathrm{m}$ resolution DTM was generated from ground points by employing the Topo-to-Raster tool in ArcGIS 10 (ESRI 2011). The applied interpolation method is based on the ANUDEM method (Hutchinson 1989). All subsequent analyses for archaeological and environmental features delineation were performed using the same LiDAR-derived DTM.

The interpretation of the LiDAR-derived DTM was performed with techniques proven to be effective for identification of linear archaeological structures (underground walls, turf walls, and ditches) and of trails in steep forested areas. For the identification of ancient features and forest road networks that are relevant for silvicultural planning and operational activities we employed two of the most common and appropriate DTM visualization models, Hill-shading from Multiple Directions and Slope. The details of these visualization mod- els are available in the literature (White et al. 2010, Bennett 2012) while general technical specifications of each visualization model and the specific parameters used are presented in the next paragraph and in Table 2 .

All visualization models were created from the same DTM in ArcGIS 10 (ESRI 2011), using the Lidar DEM Visualization Toolbox.

Hill-shading from Multiple Directions (HM) is the most common process used to visualize LiDAR-derived DTMs in archaeological prospection. Shaded relief models provide familiar views of the landscape but linear features that align with the direction of illumination are not easily visible, requiring the calculation and inspection of multiple illumination angles. This technique employs the elevation model (DTM) and calculates shade for the specified solar direction (or azimuth) and altitude (height above the horizon), thus highlighting topographic features. We used 16 solar directions, which allowed for a fine azimuth analysis and avoided the high autocorrelation that appears beyond this value. We selected a sun angle value of 35 degrees since small values $(5,10)$ are recommended for flat terrain and higher values (45) for steep terrain (Zakšek 2012), while the slope of our study area is moderately steep.

These shaded relief models work poorly in areas of substantial micro-topographic change, with deep shadows obscuring micro-topography regardless of illumination direction (Davis

Table 1 Parameters of the LiDAR flight and instrument used in this paper

\begin{tabular}{ll}
\hline Parameter & Performance \\
\hline Sensor & RIEGL LMS-Q560 \\
\hline Laser pulse frequency & $240.000 \mathrm{~Hz}$ \\
\hline Flying altitude & $600 \mathrm{~m}$ above ground \\
\hline Beam divergence & $\leq 0.2 \mathrm{mrad}=\leq 20 \mathrm{~cm}$ \\
\hline Scanning angle & $60^{\circ}\left( \pm 30^{\circ}\right)$ \\
\hline
\end{tabular}

Table 2 The visualization models generated from the LiDAR data

\begin{tabular}{lll}
\hline Visualization Models & Abbreviation & Parameters \\
\hline Hill-Shading from multiple directions & HM & $\begin{array}{l}\text { Number of direction: 16 } \\
\text { Sun elevation angle 35 }\end{array}$ \\
\hline Slope & SP & The method requires no parameter. \\
\hline
\end{tabular}


2012).

Slope (S), aspect and curvature maps are commonly used for analyzing topographic data in various geographic disciplines. Slope mapping generates a raster where slope values are assigned for each grid cell. These values are expressed in degrees of inclination from the horizontal. Slope analysis within a raster DTM determines the maximum rate of elevation change between each cell and the cells in its neighborhood. Slope degrees are saved to a new raster set and visualized as a grey-scale image. Although common for geographical applications, there has been limited application of slope for the detection of micro-topographic change relating to archaeological or forest road features, although course resolution aspect and slope terrain maps are well established in the predictive modeling of site location (Davis 2012).

The LiDAR-derived forest roads were manually digitized in ArcMap 10 (ESRI 2011) through visual analysis of the same HM and $S$ raster images that were used for mapping the ancient cultural heritage remains. The road feature was digitized at a map scale ranging from 1:500 to 1:800. The digitized line was smoothed applying the polynomial approximation with the exponential kernel (PAEK) method, by using the Smooth Line tool in ArcGIS. Small smoothing tolerance values retain more of the original detail but increase the processing time (ESRI 2011). A $10 \mathrm{~m}$ tolerance was found to be suitable for smoothing the angular appearance of the manually digitized road line, while preserving the spatial detail of the digitized line at the selected map scale. In order to ascertain whether the digitized road segments on the LiDAR-derived layers are road features, we performed a visual comparison against the most detailed available topographical maps of the study area (scale 1:25000) and against aerial photographs (pixel size: $0.5 \mathrm{~m}$ ), taken in 2009. Also, in situ ground-inspection was performed in specific areas. The polyline shapefile was exported as a keyhole markup language $(. \mathrm{kml})$ file. This file was uploaded to a Garmin GPSMap ${ }^{\circledR}$ 60s Global Positioning System (GPS) and used to spatially locate the features.

Also, the new archaeological remains discovered in the forested area after digitizing terrain models derived from LiDAR data (Opreanu et al. 2014, Roman et al. 2017) have been subsequently integrated in a single geodatabase in order to visually asses the overlapping areas.

\section{Results}

\section{Forest road mapping}

The LiDAR-derived layers, HM and S models (Fig. 2a and Fig. 2b) provide adequate feature visibility of both underground archaeological remains and aboveground forest road networks.

During the digitization process, the slope grid was drawn as a stretched grayscale image, low slopes being symbolized in white and steep ones in black, while the HM model was displayed with a $60 \%$ transparency on the slope model. Trail features were easily recognized in the HM model when illuminated from the side. The road edges were distinct in the LiDAR-derived terrain models and enabled to quickly (within 7 hours) and precisely digitize the position of the road centerline. The resulting manually digitized road network, with a total length of $72.5 \mathrm{~km}$, is shown in Figure 3.

The validation of the delineated forest road features was performed in the first stage by visual comparison against the most detailed available topographical maps. In the second stage, the exported polyline shapefile with the forest roads was uploaded to a Garmin GPS Map ${ }^{\circledR}$ 60s device and used for the ground-truthing of the digitized trail segments. The ground-inspection enabled the complete in situ geographical position validation for the forest trail features of different lengths and morphological shapes, and ranging in width from 1.5 to $2.5 \mathrm{~m}$. The full length of the tar- 

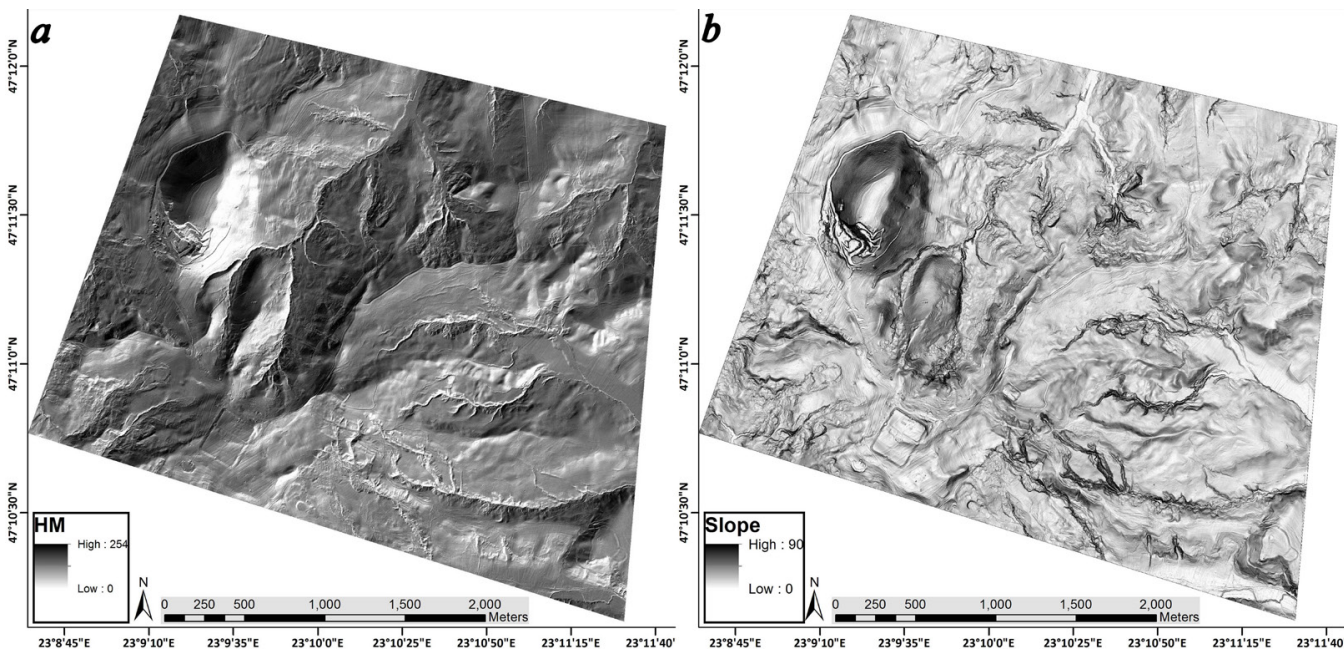

Figure 2 The LiDAR-derived DTM visualization models: (a) Hill-shading from Multiple Directions (HM); (b) Slope.

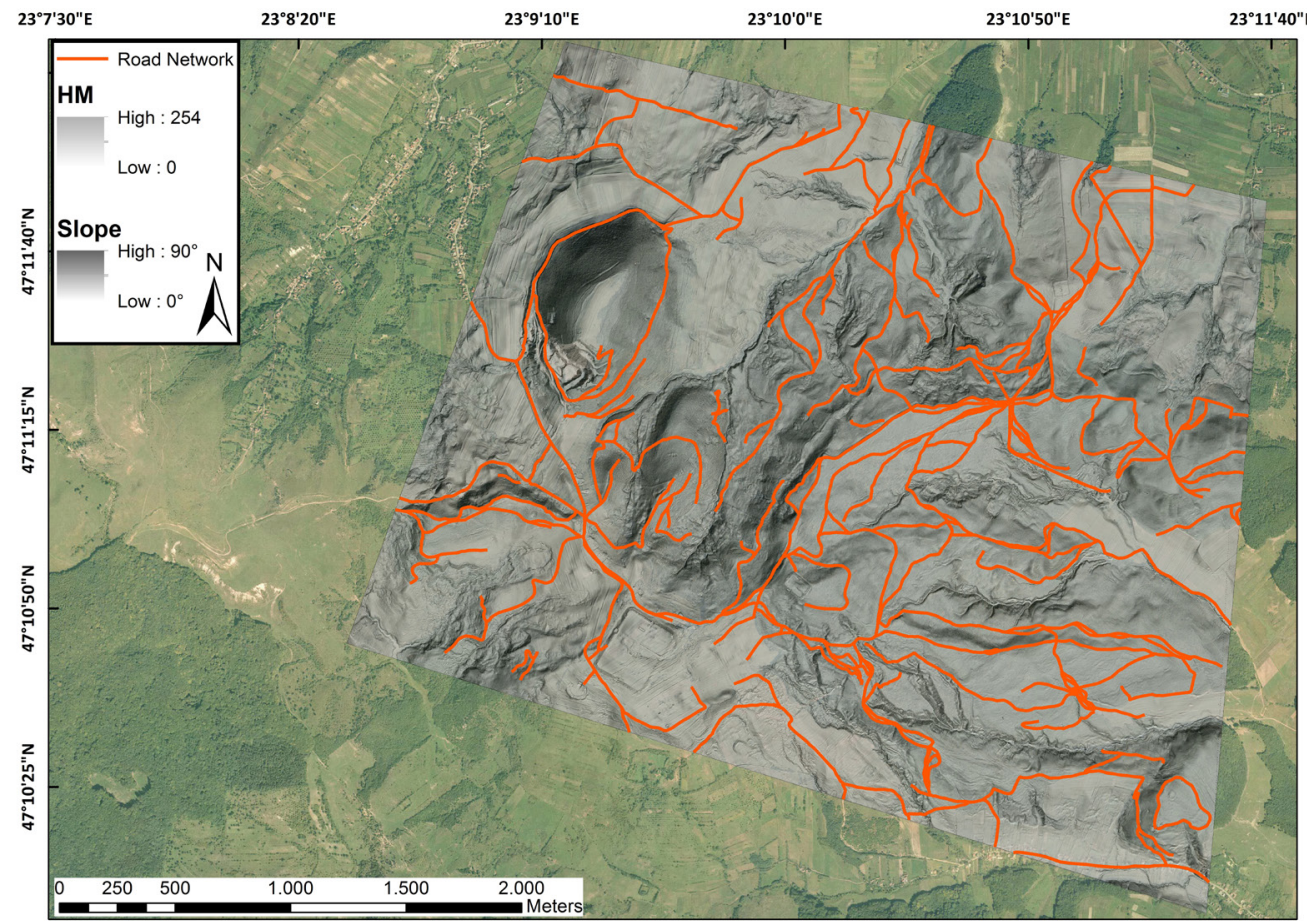

Figure 3 Road centerline digitized from LiDAR-derived HM model displayed with a $60 \%$ transparency on the slope model. 
get features was evident in the LiDAR-derived terrain models with $0.5 \mathrm{~m}$ resolution (Fig. $2 \mathrm{a}$ and Fig. 2b) starting from a scale of 1: 5000. By comparison, only $5.47 \%$ (3.97 km total length) of the road features could be digitized from the available topographical map (Military Topographic Directorate 1957, scale 1:25000). Also, because of the forest canopy, these trails are not visible from the $0.5 \mathrm{~m}$ color aerial photography at any scale (see also Fig 1d). As illustrated in Fig. 4, the high spatial resolution of the LiDAR-derived models $(0.5 \mathrm{~m})$ offers the capability of improving and updating the digital information existing in the forest cadastre by increasing the number and length of road features.

\section{Cultural heritage management and forest roads}

The complementary use of two visualization models (HM and S) for the LiDAR-derived data enabled the detection of 198 forest trail segments and mapping the spatial distribution of the underground archaeological remains. By visualizing the digitized layers on the same map, the spatial overlap between some road segments and the underground ancient remains becomes evident (Fig. 5). This pattern was confirmed in the field, where forest trails are overlaying or intersecting key elements of the ancient Roman defensive system. As observed in Fig. 5, in the center of the LiDAR survey area, on the ridges, there is an overlap between two forest road segments (one heading north and the other one heading east) and the ancient fortification structures, in this case a $4.5 \mathrm{~km}$ long turf wall. Also, these two main forest roads are represented on the topographical map surveyed in 1894 , and also on the Historical Maps of the Habsburg Empire (1769-1773: http://mapire.eu/en/), suggesting

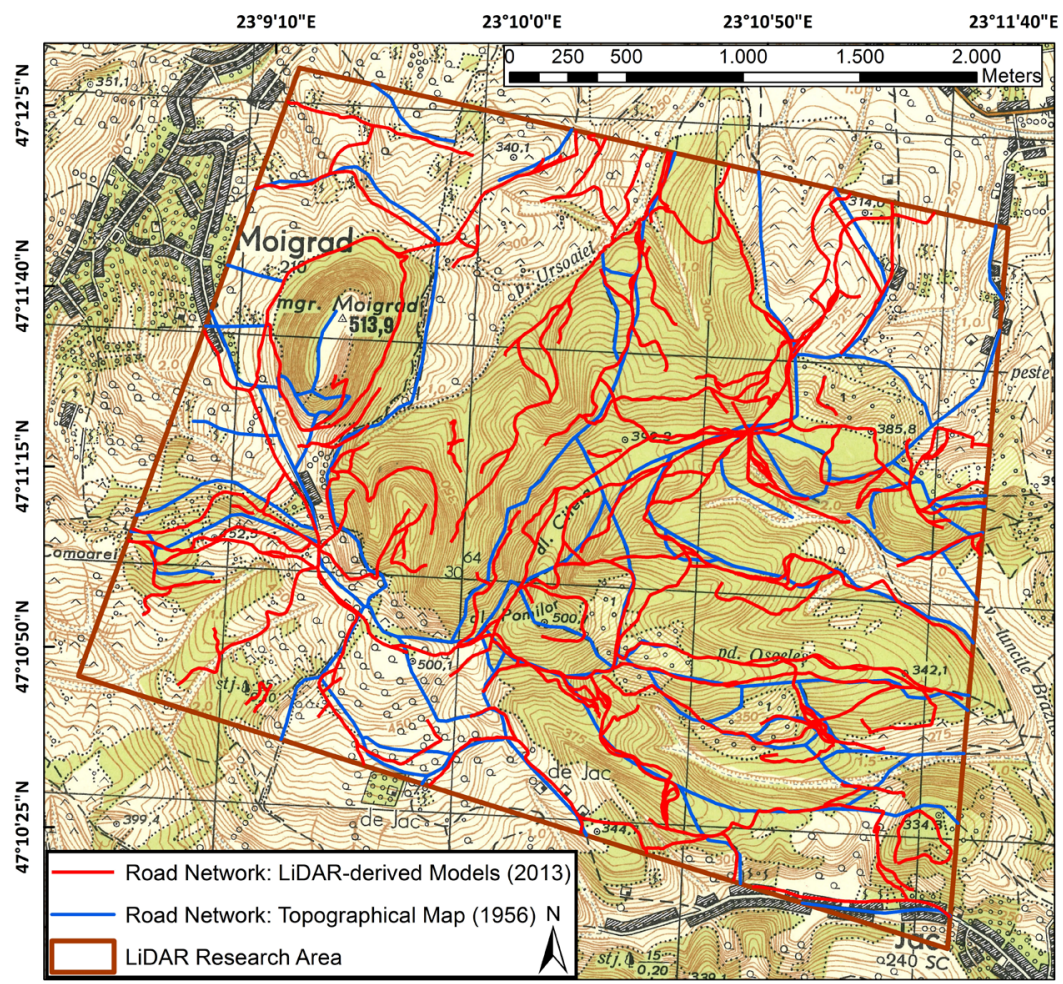

Figure 4 The road network digitized from the topographical map and from the LiDAR-derived Models 
more than 300 years usage of the ancient defensive walls as main forest roads. Moreover, even nowadays, the fortification system of the Citera Hill Fort is used as a forest road.

By integrating the spatial distribution data derived from the same LiDAR (forest roads and underground archaeological monuments), forest managers and landscape planners can achieve more efficient landscape planning and management. The transdisciplinary LiDAR approach allows detecting potential conflict areas and identifying priority sectors for archaeological discharge. Mapping the cultural heritage of the forested landscape enables to emphasize the historical land-uses and landscape changes within the study area (Fig. 6). The position of the elements belonging to the ancient Roman defensive system unveils some of the environmental changes determined by historical human activities in the landscape of that time. Thus, in contrast to the present forest dominance (at least since 1700 AD), it appears that during the Roman period in Dacia (106271 AD) at Moigrad-Porolissum, there was a different scenery. According to historical information the landscape was urbanized, with more than 10000 inhabitants and intense military activity (Paki 1988, Gudea 1989, Gudea 1996, Ardevan 1998, Tamba 2008, Bajusz 2011), which thoroughly altered the initial forests. The defense walls and ditches, watchtowers, forts and fortifications that were built strategically on the local relief (ridges) in this area also support the idea of massive deforestation for better visibility, early warning and defense against barbarian attacks.

\section{Discussions}

Ancient land use history and its legacies reflected in cultural and forest resources management were approached by combining modern technology such as LiDAR with historical

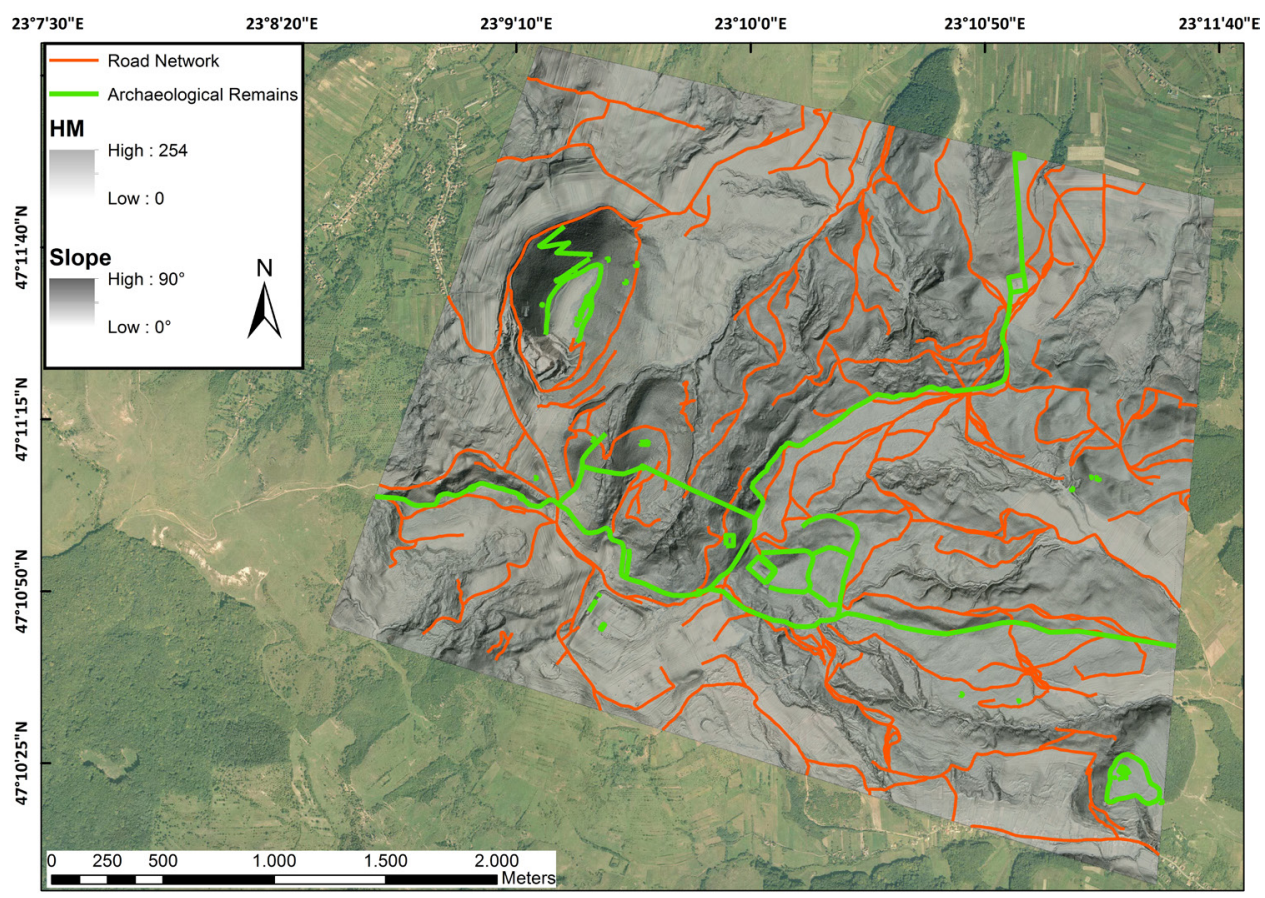

Figure 5 Lidar-derived overlapping features: present forest road network and the ancient Roman cultural heritage 
data concerning ancient human activity and the subsequent landscape changes.

$\mathrm{HM}$ and $\mathrm{S}$ models are easy to generate from the digital terrain models and widely used in many fields including geomorphology (Tarolli 2014), archaeology (Bennett 2012) and forestry (White et al. 2010). In our case these two terrain models provided good feature visibility of both underground archaeological remains of earthworks (through proxies such as soil and vegetation marks) (Bennett 2012, Opreanu et al. 2014) and aboveground forest road networks (Figure 5).

Topography was relatively easy to detect from the HM raster model (Figure 2a). However, features were easily identified only when illuminated from the side, a shortcoming reported in many other studies (Štular 2011, Tarolli et al. 2012, Tarolli 2014). Thus, road features were well defined on one aspect but difficult to distinguish on others. In this case, the slope model, whose shading is independent of aspect, was a valuable supplement, and helped surpass the obstacles of interpreting numerous shaded relief models generated from different azimuths as previously reported (White et al. 2010). Since the slope grid was rendered as a stretched grayscale image (with low slopes illustrated in white and steep slopes in black), the low gradient road area, represented in white, was well differentiated from the steep adjacent road cuts, displayed in black (Rieger et al. 1999). As expected, the length of the forest roads was significantly higher using the LiDAR extracted layers, $72.5 \mathrm{~km}$ vs. only $3.96 \mathrm{~km}$ mapped from the available topographical maps of the study area (Figure 4). This represents a significant update of the digital data available for this layer, which is essential for harvest planning, particularly in designing the access of mechanized equipment into forest stands (White et al. 2010, Cullotta et al. 2014).

The availability of highly accurate forest road maps for the study area can assist forest managers in reaching coherence between original plans and actual field activities. In addition to harvest planning and forest stand structure inventory, road maps can also be used for fighting forest fires and smuggling. Other recent studies have also reported using high-resolution LiDAR for accurately and efficiently obtaining data on road position (White et al. 2010, Craven \& Wing 2014). Using this technology, forest managers can reduce the necessity for field-based investigations focused on this essential parameter, the obtained data being also useful for many other forest inven-

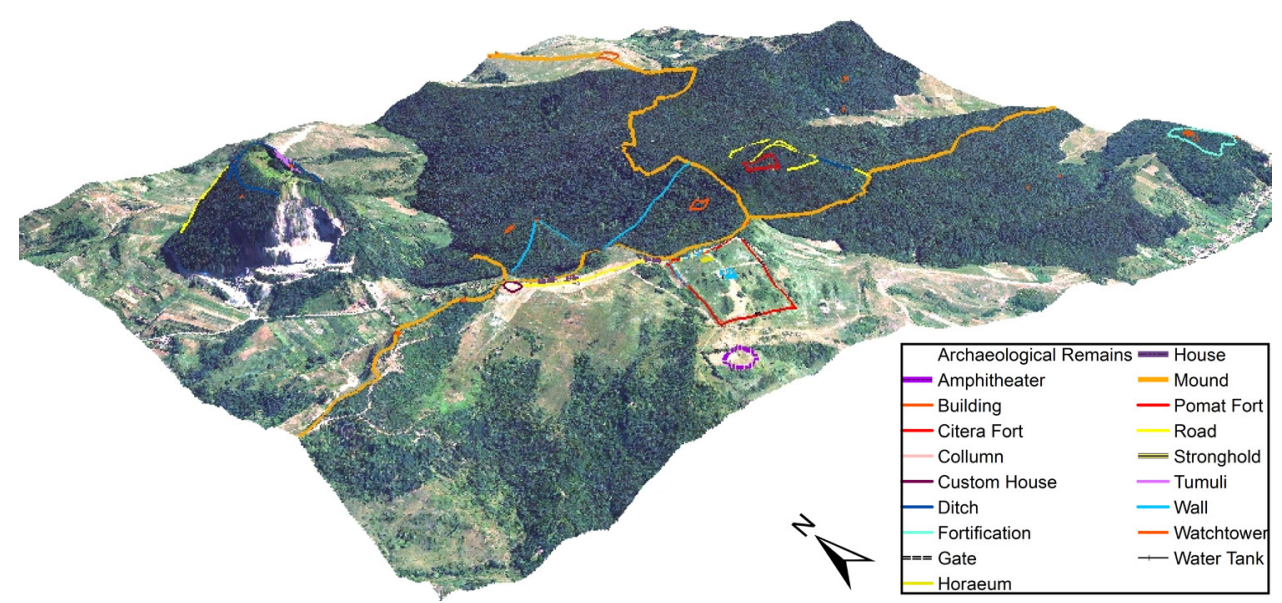

Figure 63D display of the present forested area with the ancient underground defensive structures of the Roman Empire Frontiers from Moigrad-Porolissum 
tory operations (Popescu et al. 2003, Unger et al. 2014).

The LiDAR-derived road data and cultural heritage monuments map (Figure 5) address the shortages of current databases, particularly in woodlands, and represent a helpful tool to evaluate forest cultural and social resources in order to support landscape planning and avoid infringements. The critical situation of cultural remains records in forests was also reported in other European landscapes (Štular 2011, Bollandsås et al. 2012). As emphasized in other countries rich in both archaeological artifacts and forest cover, such as Norway, these remains are exposed to the threat of destruction before their discovery primarily because of forestry practices (Risbøl et al. 2006).

In this paper, we emphasized the importance of the transdisciplinary approach when employing expensive technologies with multiple research applications at the landscape level. The same LiDAR-derived data that allowed the detection and geographical positioning of archaeological remains in previous studies (Opreanu \& Lăzărescu 2012, Opreanu et al. 2014, Roman et al. 2014, Roman et al. 2016) were also employed to explore beneath the forest canopy and map forest roads. An overlapping between the current road network, an essential layer for harvesting plans, and the spatial distribution of the ancient Roman defensive system was identified on a length of more than $4.5 \mathrm{~km}$. The strategical placement of ancient military structures on the ridges is indicative of deforestation employed by the ancient Romans for the building and usage of the defensive structures. During the Roman period, deforestation was a common practice for economic purposes like wood exploitation and agriculture clearings (Chew 2008). Moreover, besides being mandatory for defensive purposes, the deforestation event is also supported by paleoenvironmental studies that indicate a large scale deforestation within this region (Rosch \& Fischer 2000, Tanţău et al. 2003, Tanțău et al. 2006, Feurdean 2010, Tanţău et al. 2014). Oak, beech, and hornbeam show a 138 decrease in the pollen spectra during a time span overlapping the Roman period (Grindean et al. 2014). It is thus considered that, in the $2^{\text {nd }}$ century $A D$, the Roman frontiers area from Porolissum was an open landscape with intense military activities and huge defensive structures, in contrast to the present forest habitat dominance. The buried remains of these structures have generated anomalies in the soil matrix and in the topography, translating into human generated vegetation patterns that remain visible through the millennia. While these vegetation marks are well documented in grasslands and crop fields (Bennett et al. 2014), the detection of these anomalies in other LiDAR-derived models, such as the Canopy Height Model, has rarely been approached before (Hightower et al. 2014, Roman et al. 2014). These data can be translated into maps of historical land-use that are frequently unavailable (Dambrine et al. 2007). In addition to the generation of ancient land-use maps, we also need to understand how forests are influenced by particular land-use legacies in order to envisage the consequences of anthropogenic disturbances and the relevant factors in forest ecosystem restoration (Foster et al. 2003, Risbøl et al. 2015). Moreover, understanding the historical dynamics of woodlands is essential for future monitoring programs aiming to prevent unwanted developments in areas that are preserved for their cultural heritage and/or natural importance (Zerbe 2004, Birks 2005, Fraterrigo 2013).

Besides natural processes, human activities have also shaped the environment throughout history, leaving traces now embedded in the landscape. Understanding and emphasizing these values is of vital importance for the accurate perception and optimal management of the environment (Mikusiński et al. 2013). It appears that in the target area the landscape was subject to significant historical changes, consisting of a deforestation that lasted over 160 years (during the Roman period in Dacia 106-271 AD). After the Roman withdrawal from Roman Dacia in AD 271, there is no evi- 
dence for the existence of a political authority capable of maintaining and organizing such a complex type of defensive system until the beginning of the Middle Ages. This supports the idea that the defensive system was no longer in use at least for this timespan. The only possible re-use of parts of this system can be presumed for the pathway through the Ortelec valley, a point named by the medieval documents Porta Messesina $\left(9^{\text {th }}-11^{\text {th }}\right.$ century AD) (Sălăgean 2006). Hence, it seems that the landscape from Porolissum had repeatedly been subject to deforestation, abandonment and afforestation. Forest regeneration may have begun soon after the Roman withdrawal, in $271 \mathrm{AD}$. It is considered that after a severe but short disturbance a hardwood forest needs one or two generations of trees, ca. 275-300 years, to develop old-growth forest characteristics (Tyrell \& Crow 1994, Schwarz et al. 2001). For long lasting impacts, such as the Roman defensive works at Porolissum, the time needed for thorough forest regeneration is likely even longer. Therefore, in this area, it is probable that the forest reverted back to its old-growth state within the interval 500-1000 AD. The oldest available cartographic sources that display the forest cover and some of the current roads are the Habsburg Empire Historical Maps from $16^{\text {th }}$ century AD.

The time period since the land has been allowed to return to a relatively natural condition is one of the determining factors in the type and extent of persisting legacies (Foster et al. 2003, Ritter 2011). In European forests, agricultural legacies have been revealed to endure for millennia after the cessation of farming. For instance, some native species found in ancient forests were not present in the herb layer of secondary forests that established over previous croplands (Dambrine et al. 2007). Therefore, scientific knowledge regarding historical landscape change can assist different authorities, including forest services, to better understand the range of choices for action and the consequences of those decisions.

\section{Conclusions}

In this transdisciplinary study involving plant ecologists, archaeologists and a palaeoenvironment expert, LiDAR data analysis provided the base for combining the knowledge from archaeology, forestry and environmental history in order to achieve a thorough analysis of the landscape changes and to better understand the interacting processes that shaped its evolution. Since buried legacies from ancient settlements, although widespread, are easily overlooked especially in forest ecosystems, they are of particular interest to conservationists and land managers as well as to scientists. We emphasized the importance of historical records and archaeology in assessing and understanding the landscape and the effects of long-term human activities that often shaped it. Employing LiDAR remote sensing data can support the awareness of land-use legacies and the achievement of a historical perspective, particularly when forest management plans must be updated. We emphasized the deficiencies that may exist within the national cultural heritage record in forests and provides a powerful argument for using the available LiDAR data for correcting them while also providing essential data layers for forest stand inventories or resource harvesting planning. Thus, LiDAR becomes a more cost-effective way to acquire comprehensive and detailed information about human land-use in prehistoric and historic times and natural resource management and thereby to support a well-organized landscape management and protection. Moreover, forestry practices become compatible with the cultural landscape conservation and the systematical integration of all natural resources is achievable. Our results show that the LiDAR-derived data available for an area may be efficiently employed in the fields of archaeology, forestry and landscape ecology. This approach reveals historical evidence, helps to plan the future actions and to predict their consequences at ecosystem level for the 
entire landscape. However, the goal of implementing LiDAR, or other new technologies, is not just a matter of putting more dots on the map or improving the quantitative content in the relevant databases. In addition, the opportunity to work at a landscape scale can offer a different perspective based on documenting human impact on the entire landscape instead of focusing only on some areas in that region. For example, the study of biodiversity patterns in forest ecosystems needs to take into account early deforestations before establishing the natural or anthropogenic origin of the patterns in order to assess the conservation status. LiDAR offers the possibility of mapping forests over entire regions or even at continental scale. As in the case of Porolissum (or other examples from Northern Europe, Mediterranean landscapes or South America) landscape history studies can be heavily biased by priorities and professional traditions. These have major consequences for the ability to contextualize ecological processes at landscape level and thereby improve our understanding of culture and history. In the nature versus culture dichotomy, the landscape, the forest and the outfield areas are perceived primarily as nature, while they are actually often heavily marked by human impact. LiDAR offers an efficient method for improving our knowledge of the character and extent of human interaction with different landscapes - forested or otherwise. The latest advances in LiDAR, particularly the lower cost options offered by miniature devices that can be fitted on Unmanned Aerial Vehicles UAVs need to be promoted, in order to support resource management activities and facilitate the transfer of information on the social and cultural values of woodlands.

\section{Acknowledgements}

This study was supported by UEFISCDI (Romania), grant PN-II-PT-PCCA-2011-3.1-0924 (214/2012).

\section{References}

Abdi E., Sisakht S.R., Goushbor L., Soufi H., 2012. Accuracy assessment of GPS and surveying technique in forest road mapping. Annals of Forest Research 55(2): 309-317.

Abermann J., Fischer A., Lambrecht A., Geist T., 2010. On the potential of very high-resolution repeat DEMs in glacial and periglacial environments. Cryosphere 4(1): 53-65. DOI: $10.5194 / \mathrm{tc}-4-53-2010$

Anonymous, 2000. Legea nr. 5 din 2000 privind aprobarea Planului de amenajare a teritoriului naţional - Secţiunea a III-a - zone protejate [Law no. 5/2000 on approval of the national territorial arrangement Plan-Section III-protected areas]. Monitorul Oficial al României: 152(12 Aprilie), partea I.

Anonymous, 2001a. Legea nr. 378 din 2001 pentru aprobarea Ordonanţei Guvernului nr. 43/2000 privind protecţia patrimoniului arheologic şi declararea unor situri arheologice ca zone de interes naţional [Law no. $378 / 2001$ for approving Government Ordinance no. $43 / 2000$ on the protection of cultural heritage and archaeological sites as areas of national interest]. Monitorul Oficial al României: 394(18 Iulie), partea I.

Anonymous, 2001b. Legea nr. 422 din 18 iulie 2001 privind protejarea monumentelor istorice [Law no. 422/2001 on the protection of historical monuments]. Monitorul Oficial al României: 407 (24 Iulie), partea I.

Anonymous, 2002. Legea nr. 451 din 2002 pentru ratificarea Convenţiei Europene a Peisajului [Law no. 451/2002 for ratifying the European Landscape Convention]. Monitorul Oficial al României: 536(23 Iulie), partea I.

Ardevan R., 1998. Viața municipală în Dacia romană. Editura Mirton, Timișoara, $624 \mathrm{p}$.

Axelsson P., 2000. DEM generation from laser scanner data using adaptive TIN models. International Archives of Photogrammetry and Remote Sensing 33: 110-117.

Azizi Z., Najafi A., Sadeghian S., 2014. Forest road detection using LiDAR data. Journal of Forestry Research 25(4): 975-980. DOI: 10.1007/s11676-014-0544-0

Bajusz I., 2011. Amfiteatrul de la Porolissum şi amfiteatrele din provinciile romane de la Dunărea de mijloc. Editura Societatea Muzeului Ardelean [The amphitheater from Porolissum and the amphitheaters from the Roman provinces of the Middle Danube. Transylvanian Museum Society Publishing House], Cluj-Napoca, 167 p.

Bennett R. 2012. A comparison of visualization techniques for models created from airborne laser scanned data. Archaeological Prospection 19: 41-48. DOI: 10.1002/ arp. 1414

Bennett R., Cowley D., De Laet V., 2014. The data explosion: tackling the taboo of automatic feature recognition in airborne survey data. Antiquity 88: 896-905. DOI: 10.1017/S0003598X00050766

Birks J.H.B., 2005. Mind the Gap: how open were European primeval forests? Trends in Ecology and Evolution 20 (4): 154-156. DOI: 10.1016/j.tree.2005.02.001 
Bollandsås O.M., Risbøl O., Ene L.T., Nesbakken A., Gobakken T., Næsset E., 2012. Using airborne small-footprint laser scanner data for detection of cultural remains in forests: an experimental study of the effects of pulse density and DTM smoothing. Journal of Archaeological Science 39(8): 2733-2743. DOI: 10.1016/j. jas.2012.04.026

Chauchard S., Guibal F., Carcaillet C., 2013. Land-use legacies: multi-centuries years-old management control of between-stands variability at the landscape scale in Mediterranean mountain forests, France. Journal of Forest Science 1(59): 1-7.

Chew S.C., 2008. Ecological futures: what history can teach us. AltaMira Press, Plymouth, $170 \mathrm{p}$.

Craven M., Wing M.G., 2014. Applying airborne LiDAR for forested road geomatics. Scandinavian Journal of Forest Research 29(2): 174-182. DOI: $10.1080 / 02827581.2014 .881546$

Cullotta S., Bončina A., Carvalho-Ribeiro S.M., Chauvin C., Farcy C., Kurttila M., Maetzke F.G., 2014. Forest planning across Europe: the spatial scale, tools, and inter-sectoral integration in land-use planning. Journal of Environmental Planning and Management 58(8): 13841411. DOI: $10.1080 / 09640568.2014 .927754$

Dalponte M., Ørka H.O., Ene L.T., Gobakken T., Næsset E., 2014. Tree crown delineation and tree species classification in boreal forests using hyperspectral and ALS data. Remote Sensing of Environment 140: 306-317. DOI: $10.1016 /$ j.rse.2013.09.006

Dambrine E., Dupouey J.L., Laut L., Humbert L., Thinon M., Beaufils T., Richard H., Laüt L., 2007. Present forest biodiversity patterns in France related to former Roman agriculture. Ecology 88(6): 1430-1439. DOI: $10.1890 / 05-1314$

Davis O., 2012. Processing and working with LiDAR data in ArcGIS : A practical guide for archaeologists. The Royal Commission on the Ancient and Historical Monuments of Wales. Web: http://www.rcahmw.gov. uk/media/259.pdf. Accessed: 20 January 2016.

Direcţia Topografică Militară, 1957. Harta topografică a României, foaia: L-34-35-A-d, scara 1:25.000. [Military Topographic Directorate, 1957. Topographic map of Romania, sheet: L-34-35-A-d, scale 1:25.000.]

Edson C., Wing M.G., 2011. Airborne Light Detection and Ranging (LiDAR) for individual tree stem location, height, and biomass measurements. Remote Sensing 3: 2494-2528. DOI: $10.3390 / \mathrm{rs} 3112494$

ESRI (Environmental Systems Research Institute), 2011. ArcGIS Help. Web: http://resources.arcgis.com/en/ help/main/10.1/index.html\#//00660000000p000000. Accessed: 15 January 2016.

Feurdean A., 2010. Forest conservation in a changing world: natural or cultural? Example from the Western Carpathians forests, Romania. Studia Universitatis Babes-Bolyai, Geologia 55(1): 45-48. DOI: 10.5038/1937-8602.55.1.6

Foster D., Swanson F., Aber J., Burke I., Brokaw N., Tilman D., Knapp A., 2003. The importance of land-use legacies to ecology and conservation. BioScience 53(1): 77-88. DOI: 10.1641/0006-3568(2003)053[0077:TIOLUL]2.0.CO;2

Fraterrigo J.M., 2013. Landscape Legacies. Encyclopedia of Biodiversity 4: 524-530. DOI: 10.1016/b978-0-12384719-5.00388-9

García M., Riaño D., Chuvieco E., Danson F.M., 2010. Estimating biomass carbon stocks for a Mediterranean forest in central Spain using LiDAR height and intensity data. Remote Sensing of Environment 114: 816-830. DOI: 10.1016/j.rse.2009.11.021

Grindean R., Tanţău I., Fărcaş S., Panait A., 2014. Middle to late holocene vegetation shifts in the NW Transylvanian lowlands (Romania). Studia Universitatis BabesBolyai, Geologia 59(1): 29-37. DOI: 10.5038/19378602.59.1.2

Gudea N., 1988. Porolissum. Cheia de boltă a apărării Daciei Porolissensis. [Porolissum. The keystone of Dacia Porolissensis defence.] Acta Musei Porolissensis 12:195-214.

Gudea N., 1989. Porolissum. Un complex arheologic daco-roman la marginea de nord a Imperiului Roman. [Porolissum. A Dacian-Roman archaeological complex at the northern border of the Roman Empire.] Acta Musei Porolissensis 13: 1-1178.

Gudea N., 1996. Porolissum. Un complex daco-roman la marginea de nord a Imperiului Roman II. Vama romană. Monografie arheologică. Editura Biblioteca Musei Napocensis, [Porolissum. A Dacian-Roman complex at the northern border of the Roman Empire II. The Roman customs house. Archaeological monography. Biblioteca Musei Napocensis Publishing House], Cluj-Napoca, $449 \mathrm{p}$.

Harpold A.A., Marshall J.A., Lyon S.W., Barnhart T.B., Fisher B.A., Donovan M., Brubaker K.M., Crosby C.J., Glenn N.F., Glennie C.L., Kirchner P.B., Lam N., Mankoff K. D, McCreight J.L., Molotch N.P., Musselman K.N., Pelletier J., Russo T., Sangireddy H., Sjöberg Y., Swetnam T., West N., 2015. Laser vision: lidar as a transformative tool to advance critical zone science. Hydrology \& Earth System Sciences 19: 2881-2897. DOI: $10.5194 /$ hess-19-2881-2015

Hightower J., Butterfield A., Weishampel J., 2014. Quantifying ancient Maya land use legacy effects on contemporary rainforest canopy Structure. Remote Sensing 6(11): 10716-10732. DOI: 10.3390/rs61110716

Historical Maps of the Habsburg Empire., 1769-1773. Web: http://mapire.eu/en/. Accessed: 20 December 2015.

Hutchinson M.F., 1989. A new procedure for gridding elevation and stream line data with automatic removal of spurious pits. Journal of Hydrology 106: 211-232. DOI: 10.1016/0022-1694(89)90073-5

Hyyppä J., Yu X., Hyyppä H., Vastaranta M., Holopainen M., Kukko A., Kaartinen H., Jaakkola A., Vaaja M., Koskinen J., Alho P., 2012. Advances in forest inventory using airborne laser scanning. Remote Sensing 4: 1190-1207. DOI: 10.3390/rs4051190 
Lee S.J., Jung R.K., Yun S.C., 2013. GIScience \& Remote Sensing the extraction of forest $\mathrm{CO} 2$ storage capacity using high-resolution airborne Lidar data. GIScience \& Remote Sensing 50 (2): 154-171.

Lefsky M.A., Turner D.P., Guzy M., Cohen W.B., 2005. Combining Lidar estimates of aboveground biomass and Landsat estimates of stand age for spatially extensive validation of modeled forest productivity. Remote Sensing of Environment 95: 549-558. DOI: 10.1016/j. rse.2004.12.022

Mikusiński G., Blicharska M., Antonson H., Henningsson M., Göransson G., Angelstam P., Seiler A., 2013. Integrating ecological, social and cultural dimensions in the implementation of the landscape convention. Landscape Research 38(3): 384-393. DOI: 10.1080/01426397.2011.650629

Opreanu C.H., 1998. Dacia Romană şi Barbaricum. Editura Mirton, [Roman Dacia and the Barbaricum. Mirton Publishing House] Timişoara, $230 \mathrm{p}$.

Opreanu C.H., Lăzărescu V.A., 2012. Seeing the Unseen. Landscape archaeology on the northern frontier of the Roman Empire at Porolissvm (Romania). Ephemeris Napocensis 22: 356-366.

Opreanu C.H., Lăzărescu V.A., Roman A., Ursu T.M., Fărcaş S., 2014. New light on a Roman Fort based on a LiDAR survey in the forested landscape from Porolissvm. Ephemeris Napocensis 24: 71-86.

Opreanu C.H., Lăzărescu V.A., Ştefan D., 2013. Noi cercetări la Porolissum. [New research at Porolissum.] Analele Banatului 21: 83-106.

Opreanu C.H., Lăzărescu, V.A., Ştefan D., 2013. Recent geophysical surveys at Porolissum. In Stavilă A., Micle D., Cîntar A., Floca C., Forţiu S. (eds.), Interdisciplinaritate în arheologie şi istorie. ArheoVest JATEPress, Timişoara, pp. 509-524.

Paki A., 1988. Populaţia Daciei Porolissensis. I. Porolissum, Acta Musei Porolissensis 12: 215-226.

Popescu S.C., 2007. Estimating biomass of individual pine trees using airborne Lidar. Biomass and Bioenergy 31(9): 646-655. DOI: 10.1016/j.biombioe.2007.06.022

Popescu S.C., Wynne R.H., 2004. Seeing the trees in the forest: Using Lidar and multispectral data fusion with local filtering and variable window size for estimating tree height. Photogrammetric Engineering \& Remote Sensing 70(5): 589-604. DOI: 10.14358/PERS.70.5.589

Popescu S.C., Wynne R.H., Nelson R.F., 2003. Measuring individual tree crown diameter with Lidar and assessing its influence on estimating forest volume and biomass. Canadian Journal of Remote Sensing 29(5): 564-577. DOI: $10.5589 / \mathrm{m} 03-027$

Rieger W., Kerschner M., Reiter T., Rottensteiner F., 1999. Roads and buildings from laser scanner data within a forest enterprise. International Archives of Photogrammetry and Remote Sensing 32: 185-91.

Risbøl O., Briese C., Doneus M., Nesbakken A., 2015. Monitoring cultural heritage by comparing DEMs derived from historical aerial photographs and airborne laser scanning. Journal of Cultural Heritage 16(2): 202-
209. DOI: 10.1016/j.culher.2014.04.002

Risbøl O., Gjertsen A.K., Skare K., 2006. Airborne laser scanning of cultural remains in forests: some preliminary results from a Norwegian project. Bar International Series 1568: 107-112.

Ritter E., 2011. Forests in landscapes. The myth of untouched wilderness. In: Ritter E. (ed.), New Perspectives on People and Forests. Springer, pp. 11-28. DOI: 10.1007/978-94-007-1150-1_2

Roman A., Ursu T.M., Fărcaş S., Lăzărescu V.A., Opreanu C.H., 2014. Perspectives: remotely sensing the buried past of present vegetation. In: Pfeifer N., Zlinszky A. (eds.), Proceedings of The International Workshop on Remote Sensing and GIS for Monitoring of Habitat Quality. Vienna University of Technology, Vienna, pp. 108-112.

Roman A., Ursu, T.M., Fărcaş S., Lăzărescu V.A., Opreanu C.H., 2015. Using airborne LiDAR for detection and morphologic analysis of waterbodies obscured by the forest canopy. Transylvanian Review of Systematical and Ecological Research. The Wetlands Diversity 17(1): 1-14.

Roman A., Ursu T.M., Lăzărescu V.A., Opreanu C.H., 2016. Multi-sensor surveys for interdisciplinary landscape analysis and archaeological feature detection at Porolissum. In: Opreanu C.H., Lăzărescu V.A. (eds.) Landscape Archaeology on the Northern Frontier of the Roman Empire at Porolissum. An Interdisciplinary Approach. Mega Publishing House, Cluj-Napoca, pp. 237-261.

Roman A., Ursu T.M., Lăzărescu V.A., Opreanu C.H., Fărcaş S., 2017. Visualization techniques of ALS-derived DTM in forested steep terrain: detecting archaeological remains in the subsurface. Geoarchaeology-An International Journal. DOI:10.1002/gea.21621

Rosch M., Fischer E., 2000. A radiocarbon dated Holocene pollen profile from the Banat Mountains (Southwestern Carpathians, Romania). Flora 195(3): 277-286.

Saeys W., Lenaerts B., Craessaerts G., De Baerdemaeker J., 2009. Estimation of the crop density of small grains using LiDAR sensors. Biosystems Engineering 102(1): 22-30. DOI: 10.1016/j.biosystemseng.2008.10.003

Sălăgean T., 2006. Țara lui Gelou: contribuţii la istoria Transilvaniei de Nord în secolele IX-XI, Editura Argonaut, [The country of Gelou: contributions to the history of northern Translylvania in the centuries IX-XI, Argonaut Publishing House], Cluj-Napoca, 236 p.

Scazzosi L., 2004. Reading and assessing the landscape as cultural and historical heritage. Landscape Research 29(4): 335-351. DOI: 10.1080/0142639042000288993

Schwarz P.A., Fahey T.J., Martin C.W., Siccama T.G., Bailey A., 2001. Structure and composition of three northern hardwood-conifer forests with differing disturbance histories. Forest Ecology and Management 144:201212. DOI: $10.1016 / \mathrm{S} 0378-1127(00) 00371-6$

Sofia G., Dalla Fontana G.D., Tarolli P., 2014. High-Resolution topography and anthropogenic feature extraction: testing geomorphometric parameters in floodplains. Hy- 
drological Processes 28(4): 2046-2061. DOI: 10.1002/ hyp. 9727

Štular B., 2011. The use of Lidar-derived relief models in archaeological topography. The Kobarid Region (Slovenia) case study. Arheoloski Vestnik 62: 393-432.

Tamba D.G., 2008. Porolissum: aşezarea civilă (vicus Militaris) a Castrului Mare. Observaţii în legătură cu aşezările civile ale castrelor de trupe auxiliare din Dacia Porolissensis. Editura Mega [Porolissum: the civian settlement (vicus Militaris) of the Big Fort. Observations regarding the civilian settlements of the auxiliary troupes from Dacia Porolissensis. Mega Publishing House], Cluj-Napoca, 450 p.

Tanţău I., Feurdean A., De Beaulieu J.L., Reille M., Fărcaş S., 2014. Vegetation sensitivity to climate changes and human impact in the Harghita mountains (Eastern Romanian Carpathians) over the past 15000 Years. Journal of Quaternary Science 29(2): 141-152. DOI: 10.1002/jqs.2688

Tanțău I., Reille M., de Beaulieu J.L., Fărcaș S., 2006. Late glacial and Holocene vegetation history in the southern part of Transylvania (Romania): Pollen analysis of two sequences from Avrig. Journal of Quaternary Science 21(1): 49-61. DOI: $10.1002 /$ jqs.937

Tanţău I., Reille M., de Beaulieu J.L., Fărcaş S., Goslar T., Paterne M., 2003. Vegetation history in the Eastern Romanian Carpathians: Pollen analysis of two sequences from the Mohoş Crater. Vegetation History and Archaeobotany 12(2): 11-25. DOI: 10.1007/s00334-0030015-6

Tarolli P., 2014. High-resolution topography for understanding earth surface processes: Opportunities and challenges. Geomorphology 216: 295-312. DOI: 10.1016/j.geomorph.2014.03.008

Tarolli P., Sofia G., Dalla Fontana G., 2012. Geomorphic features extraction from high-resolution topography:
Landslide crowns and bank erosion. Natural Hazards 61(1): 65-83. DOI: 10.1007/s11069-010-9695-2

Tyrrell L.E., Crow T. R., 1994. Structural characteristics of old-growth hemlock-hardwood forests in relation to age. Ecology 75: 370-386. DOI: 10.2307/1939541

UN Educational, Scientific and Cultural Organisation (UNESCO), 1972. Convention Concerning the Protection of the World Cultural and Natural Heritage, 16 November 1972. Web: http://www.refworld.org/docid/4042287a4.html. Accessed 28 January 2016.

Unger D.R., Hung I.K., Brooks R., Williams H., 2014. Estimating number of trees, tree height and crown width using Lidar data. GIScience \& Remote Sensing 51(3): 227-238. DOI: 10.1080/15481603.2014.909107

Whelley P.L., Glaze L.S., Calder E.S., Harding D.J., 2014. LiDAR-derived surface roughness texture mapping: Application to Mount St. Helens pumice plain deposit analysis. IEEE Transactions on Geoscience and Remote Sensing 52(1): 426-438. DOI: 10.1109 / TGRS.2013.2241443

White R.A., Dietterick B.C., Mastin T., Strohman R., 2010. Forest roads mapped using LiDAR in steep forested terrain. Remote Sensing 2(4): 1120-1141. DOI: 10.3390/rs2041120

Wulder M.A., Bater C.W., Coops N.C., Hilker T., White J.C., 2008. The role of LiDAR in sustainable forest management. The Forestry Chronicle 84(6): 807-826. DOI: $10.5558 / \mathrm{tfc} 84807-6$

Zakšek K., Oštir K., Kokalj Ž., 2011. Sky-View Factor as a relief visualization technique. Remote Sensing 3: 398415. DOI: $10.3390 / \mathrm{rs} 3020398$

Zerbe S., 2004. Influence of historical land use on present-day forest patterns: A case study in south-western Germany. Scandinavian Journal of Forest Research 19(3): 261-273. DOI: 10.1080/02827580410029291 